\title{
The Influence of Television Advertisement on Purchase Decision of Men's Product of Facial Wash
}

\author{
Ira Valentina Silalahi, Harini Fajar Ningrum, Rasna Ulfah \\ Magister Manajemen, Sekolah Pascasarjana \\ Universitas Pendidikan Indonesia \\ iravalentinasilalahi@student.upi.edu
}

\begin{abstract}
Consumer interest of facial wash for men product is so high, it is because almost every toiletries company produce segmented product, especially product for men. So, it makes many toiletries company work harder, persist with more powerful, and keep continuing to do the innovation. Therefore, it takes some effort for toiletries company which produce men product (in this case facial wash for men) to make the right marketing strategy. One of marketing strategy that can be applied is to centralize communication pattern in attracting consumer attention and affect consumers to choose and buy their product through various electronic media, one of them is television advertisement. This research aims to 1) Obtain findings about consumer responses on television advertisement of facial wash for men product, 2) Obtain findings about consumer purchasing decision on facial wash for men product, and 3) Obtain findings about influence of the television advertisement facial wash for men product on purchase decision. The objects of this research are male consumers who use facial wash for men at Yogya Toserba Raya Cihampelas Walk Bandung. The independent variable in this research is television advertisement (X) and dependent variable is purchasing decision (Y). This research used verification description and the method is explanatory survey with purposive sampling technique with 100 respondents. Data analysis technique that's used is simple linear regression with SPSS 23.0 computer software. The result from this research states that advertisement on television media has an influence about $53,30 \%$ corresponds to the purchasing decision. That means either on the partial or simultaneous have a significant influence from performance of the television advertisement in purchasing decision. In this research, there are some findings, as follows: 1) Performance of the television advertisement such as mission, message, and media are executed very well, 2) The purchasing decision for facial wash for men is also executed well by the male consumer at Yogya Toserba Raya Cihampelas Bandung, and 3) Performance of the Television advertisement has a strong influence in accordance to purchasing decision, and the selecting product dimension has a high influence compare to other dimensions. Based on the result, the research recommends that television advertisement increases consumer's purchasing decision. The company which produce facial wash for men needs to improve their promotional strategy by using television advertisement with more innovative and creative, this is the main key to attract consumers in order to increase purchase.
\end{abstract}

Keywords-Television Advertisement; Purchase Decision.

\section{INTRODUCTION}

Consumer interest of facial wash for men product is so high, it's because almost every toiletries company produce segmented product, especially product for men. So, it makes many toiletries company work harder, persist with more powerful, and keep continuing to do the innovation, it also affects the growth of toiletries industry in Indonesia. According to the SWA Magazine (business magazine) in 2011, toiletries industry was rank fourth out of 10 major domestic industries in Indonesia, with a market size of 29. It is influenced by Indonesian public awareness and the needs of products toiletries in everyday life.

Initially, the majority of demand for products toiletries dominated by woman, so most of the toiletries company only produce products that are intended for woman only. But along with the advent of the metrosexual phenomenon was first coined by Mark Simpson in salon magazine edition of July 2002, the trend and lifestyle began to shift (getLIFE! Magazine, Issue 06). The phenomenon affects a man's need for products that also affect toiletries companies to expand its business by producing toiletries for men, particularly skin care products.

According to the predictions of the numbers in United States, in 1990, it was only $4 \%$ of men who admitted to use skin care products. But in 2015, the use of skin care products by men has reached $50 \%$. This figure shows that many men begin to participate in the purchase of toiletries products that had only monopolized by women only (Marketing 10/VIII/2008).

Male personal care products consist of product categories represented by the criteria of the sections that are considered important in the appearance of a man that is the smell of the body, hair and skin face. Nielsen retail audit shows total sales product categories for men and its contribution in the growth of the market share for men's toiletries products. In the first rank, cologne or perfume accounted for $68.20 \%$, and a facial wash is ranked second with a contribution of $16.60 \%$. Furthermore, in the third place shampoo with a contribution of $7.30 \%$ and in the next rank occupied by hand and body lotion and moisturizer (Marketing 07/XI/July 2011). Data illustrate that this time the men did not hesitate in spending money to buy toiletries products, either in the form of hair care products, skin care and body fragrances. 
Products related to the image that became symbolic of the social collectivity associate as a lifestyle. Thus advertising became one of the participating agencies formulate cultural frameworks lifestyle imagery continues to hit people's lives, especially men. The market potential of men in Indonesia at this time is very large, it can be seen from some industry ad spending basically market is dominated by men, particularly for facial cleansing soap product that is one of the largest contributor to the increasing growth of toiletries industry in Indonesia. Increased advertising spending toiletries products for men that occurred in this industry encourages companies soap cleanser for competing offers advantages of each product. This prompted the creation of soap cleanser product attributes specifically created to meet the needs and desires of men.

There are four large companies that produce products soap facial cleanser that is devoted to male consumers. These companies are currently competing in developing the benefits of its products through a variety of innovations in order to dominate the market competition. Competition in this industry, dominated by two large companies namely PT. Unilever Indonesia and PT. Kao Indonesia. As a pioneer in facial cleansing soap industry in Indonesia, PT. Kao Indonesia entered the market with the Men's Biore men. The success of PT. Kao Indonesia with Men's Biore is followed by PT. Unilever by issuing Vaseline for Men. PT. Loreal Indonesia issued Garnier for Men. PT. Mandom Indonesia previously had success with hair styling market issued Gatsby to enter the industry soap cleanser.

Many variations of facial cleansing products for men turned consumers have a variety of alternative choices of products, it is certainly affected purchasing decisions of consumers towards a particular product. Purchasing decisions arise because of an objective assessment or for their emotional impulse. Emotional role is important because it is also a driving factor for consumer purchase behavior and emotional concerns fundamental psychological aspects that ultimately very influential on consumer perceptions in assessing a brand (Bernard T. Widjaja, 2009:9). To influence purchasing decisions, then one way that can be done by the company is to carry out promotional activities. According Buchari Alma (2004: 181) that "the main purpose of the campaign is to inform, attract further attention and influence increased sales". Through the promotion, companies can communicate with consumers, so the end result of the communication process is expected consumers choose to buy products they offer than those offered by competitors.

Advertising is one of the marketing activities for manufacturers to get consumers to its products through a marketing communications to inform, persuade and remind consumers on products marketed by the company. In the development of advertising, advertising can be done a variety of media such as print media (newspapers and magazines) and electronic media (radio and television). Based on the results of pre-study through a survey of 100 respondents in Yogya Toserba Raya Cihampelas Walk Bandung conducted by researchers showed that advertising is most consumers consider the purchase of products other than facial cleanliness result factors, price, brand, and materials. It shows that the marketing communications through advertising plays an important role in encouraging the consumer to decide on the purchase of products. Therefore, advertising factors selected in this study because it is known most influence purchasing decisions of products facial wash for men. In addition, based on the pre-study previous survey showed that advertising via television selected respondents by $73 \%$ as an advertising medium is most effective, because it is often used or seen by consumers to find a product after magazines, social media and other media used in promotional activities. According to Sandra Moriarty (2011: 330), a television commercial used because it works like a movie, telling the story, evoke emotions, create a fantasy, and provide a strong visual impact.

Implementation of the strategy in television advertising is expected to increase sales of products facial wash for man. According Morrisan (2010: 114), the ad provides detailed information about a brand and how a brand can satisfy the purpose or motive consumer purchases. Fandy Tjiptono (2008: 226), the ad form of indirect communication, which was realized on the information on the advantages or benefits of the product, which is structured such that cause a sense of fun that will change someone's mind to make a purchase.

The purpose of this study is to: 1) figure out the consumer responses on television advertisement of facial wash for men product, 2) find out consumer purchasing decision on facial wash for men product, and 3) find out the influence of the television advertisement facial wash for men product on purchase decision.

\section{THEORETICAL BASIS}

According to Kotler and Armstrong (2012:33) "marketing as the process by which companies create value for customers and build strong customers relationships in order to capture value from customers in return". Meanwhile according to Kotler and Armstrong (2012:51-52) "marketing mix is a set of marketing used to achieve the marketing purposes“. There are four types of marketing mix called The Four Ps, they are product, price, place, and promotion. As one of the Four Ps, promotion is a way of the company to do marketing communication. There are four marketing communication mix which is connected to each other, they are: advertising, selling promotion, public relations, and personal selling.

Kotler and Keller (2012:478) describe that marketing communication consists of Advertising, Sales Promotion, Events and Experience, Public Relation and Publicity, Direct Marketing, Interactive Marketing, Word Of Mouth Marketing, and Personal Selling. Advertising is a marketing communication way done by the company to give information to the consumer through media.

According to Kotler and Armstrong (2012:405) "advertising is any paid form of non-personal presentation and promotion of ideas, goods, or service by an identified sponsor". Kotler and Keller (2012:504) state that the advertising decision consists of Mission, Money, Message, Media, and Measurement. 
This study used advertising dimension of advertising proposed by Kotler and Keller (2012:504), that is 1)Mission; 2)Message; and 3)Media. Advertising isn't complete without using media. Advertising media is a place or tool used by the organization to tell message to the people.

According to Wilbur (2009:1) "television is the important medium for advertiser". It is supported by Kotler and Keller (2009:205) who state that television advertisement is the most powerful media and has wider range ability to catch consumer.

Advertisement is treated as an effective marketing strategy to convince the consumer in terms of buying products. According to Kotler and Armstrong (2012:149) "purchase decision is the buyer's decision about which brand to purchase". The company needs to understand the purchase decision behavior especially advertisement which is the part of company strategy influences consumer behavior. According to Kotler and Keller (2009:178) the dimensions of purchase decision are as follows: choosing the product, choosing the brand, choosing the supplier, time of buying, total of buying. These dimensions are assumed can affect the purchase decision.

According to the definition above, it can be concluded that television can be used as media to influence the consumer in buying service or goods. This is the paradigm in this study:

\begin{tabular}{|c|c|}
\hline Advertising & Buying decision \\
\hline $\begin{array}{ll}\text { 1. } & \text { Mission } \\
\text { 2. } & \text { Message } \\
\text { 3. } & \text { Media }\end{array}$ & $\begin{array}{l}\text { 1. Choosing the } \\
\text { product } \\
\text { 2. Choosing the brand } \\
\text { 3. Choosing the } \\
\text { supplier } \\
\text { 4. Time of buying } \\
\text { 5. Total of buying }\end{array}$ \\
\hline
\end{tabular}

Fig. 1. Research Paradigms

\section{RESEARCH METHODS}

This study used the marketing approach especially about advertising in television towards buying decision of man facial wash. The object of the research was the advertisement consists of mission, message and media as the independent variable. Meanwhile the problem of this study is treated as dependent variable which is the choosing product, brand, supplier, time of buying and buying method.

The object of this study is consumer's reaction about the advertisement and how they decide to buy the product. The subject of this study is the man consumer who buys the product at Toserba Griya, Cihampelas Walk. This study conducted from January 2012 until April 2012. The method of this study is cross sectional method. The type of the study is description and verification by gathering the data.
The population in this study was the user of man facial wash in Yogya Toserba Raya Cihampelas Walk Bandung which is around 4.464 user per year. The sample was taken by using Slovin Formula, thus it can be found there were 100 respondents. The analysis technique used is aimed to find the influence of the television (X) towards the buying decision (Y) by using a simple linear regression.

\section{RESULTS AND DISCUSSIONS}

According to the result, It is concluded that there is a strong relation between influence of advertisement in television and buying decision, where the correlation value (r) is 0,730 . It means that the influence of the television and buying decision has strong correlation value between $(0,600$ $0,799)$. This is proven by calculating the coefficient of determination squared correlation coefficient. The result shows that the value of correlation coefficient is $53 \%$, it means that the $53,33 \%$ buying decision is affected by television. Meanwhile, $46,7 \%$ is affected by another factor.

The hypothesis test is used to compare the $t$ with $t$ tabel. The significant test used the alpha 0,05 in one side test with degree of freedom $(\mathrm{dk}) \mathrm{n}-2,(\mathrm{dk})=70-2$. Thus, since the $\mathrm{dk}=68$, the $t_{\text {count }}$ and $t_{\text {table }}$ have $5 \%$ in terms of error precentage. According to the notion above, hyphothesis is accepted when

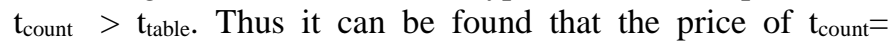
$10.584>\mathrm{t}_{\text {table }}=1,99$ which means that there is a positive influence between advertisement in television and buying decision.

These notions are gathered through the hypothesis test by using simple linear regression method. The result shows a big change of buying decision (Y) which follows the change in television advertisement (X (20.345). It means that if there is no advertisement $(X=0)$, so the buying decision is 20.345 in a unit value. Coefficient regression is 1.125 in a unit value means there is a raising in television advertisement, there will be a raising decision buying event in 1.125 a unit value. On the other hands, if there is a decreasing of advertisement in television, it will also decrease the buying decision 1.125a unit value. The formula is $((\mathrm{Y})=20.345+1,125 \mathrm{X})$ where the coefficient of determination squared correlation coefficient and the result is $53 \%$. It means the using of television can influence the decision buying in 53,3\%.

One of the factors that can influence the buying decision is advertisement in television. Facial wash for men advertisement successfully describes the benefits of its product which makes a pleasure feeling to consumer to buy the product in buying decision.

In terms of dimension advertising, message gives the biggest contribution since the men facial wash educates the consumer about how important washing the face even for men. Thus, it triggers the consumers to buy the product. Through the television, the strength and benefits from the products can be informed. The consumers who didn't know about the product will notice about the presence of the product and buy the product in the end. It is in line with Steiner in Sigit Santosa, (2009:4) "advertisement can lead the consumers 
from the not knowing phase until choosing and consuming the products."

According to the notion above, it is concluded that television advertisement can influence the consumers in making decision of buying the man facial wash in Yogya Toserba Raya Cihampelas Walk Bandung.

\section{CONCLUSIONS AND RECOMMENDATIONS}

Conclusions

Seen from the dimensions of research, it can be concluded that television advertisement has a high impact. This is evidenced by the success of television advertisement convey messages in a product and make a purchase decision. Select product is the highest dimension in the variable purchase decision. This is because in the process of product selection, consumers choose a facial wash decisions based on the merits, as well as the quality of the product packaging. So it can be said that television advertisement had a positive influence on the buying decision is indicated by the high level and the strong correlation between the two, that is, if the media campaign through television advertisement increases it will increase the purchasing decisions as well.

\section{Recommendations}

The implementation of advertisement in television influences significantly in raising the buying decision. However, there is some recommendation such as refining the concept, adding intensity of the activation so that, there product and the consumer will have stronger relationship, maximizing the social media such as twitter, facebook, etc, choosing endorser of the product by focusing more on the message of the product. To add, in increasing the amount of purchasing, it is suggested to provide more variety of products related to the needs of consumer. It will lead the consumers to have satisfaction and re-purchasing decision. Moreover, it is suggested that the company keeps or makes even better the promotion strategy by informing more innovative and creative television advertisement. The company needs to present new approach to consumer such as by combining the humor or eye catching advertisement so that the company can get more consumers without forgetting the old consumer.

\section{REFERENCES}

[1] Alma, Buchari. (2008) Manajemen Pemasaran. Edisi Revisi. Bandung: Alfabeta.

[2] Market Size Industri Domestik Indonesia (2011). SWA 12/XXVI/ 19-22 Juni 2011

[3] Kotler, Philip dan Kevin Lane Keller. (2009). Manajemen Pemasaran.

[4] Kotler. Philip and Gary Amstrong. (2012). Principles of Marketing, New Jersey:Pearson Prentice Hall

[5] Kotler, Philip dan Kevin Lane Keller. (2012). Marketing Management $14^{\text {th }}$ Edition New Jersey:Pearson Prentice Hall.

[6] Main Shopper Indonesia 2008. (2008). Marketing 10/VIII/ Oktober 2008.

[7] Morissan, M. A. (2010). Periklanan: Komunikasi Pemasaran Terpadu. Kencana. Jakarta: Gramedia.

[8] Pertumbuhan Pasar Produk Perawatan Diri Pria. (2011). Marketing 07/XI/Juli 2011.

[9] Santosa, Sigit. (2009). Creative Advertising. Jakarta: Erlangga.

[10] Simpson, Mark. (2002). Fenomena Sosial: Pria Metroseksual. getLIFE! Edisi 06, Hal. 39, Bandung.

[11] Tjiptono, Fandy, Chandra, G., dan Adriana, D. (2008). Pemasaran Stratejik. Yogyakarta: Andi Offset.

[12] Wilbur, K. C., Goeree, M. S.,and Ridder, G. (2009). Effect of Advertising and Product Placement on Television Audience. Dalam Marshall Research Paper Series Working Paper MKT 09-09 [online], Vol. 1 (1), $40 \quad$ halaman. http://ssrn.com/abstract $=1151507$. 